\title{
First Generation Education Charters in Portugal: Intentions and Achievements
}

\section{Lúcia Isabel Ribeiro Santos¹, António Manuel Rochette Cordeiro², Joaquim Luís Medeiros Alcoforado ${ }^{1}$}

${ }^{1}$ Faculty of Psychology and Educational Sciences, University of Coimbra, Coimbra, Portugal

${ }^{2}$ Faculty of Arts and Humanities, University of Coimbra, Coimbra, Portugal

Email: luciarsantos@gmail.com, rochettecordeiro@fl.uc.pt, lalcoforado@fpce.uc.pt

How to cite this paper: Santos, L. I. R., Cordeiro, A. M. R., \& Alcoforado, J. L. M. (2021). First Generation Education Charters in Portugal: Intentions and Achievements. Open Journal of Political Science, 11, 328-346.

https://doi.org/10.4236/ojps.2021.112022

Received: December 14, 2020

Accepted: April 23, 2021

Published: April 26, 2021

Copyright $\odot 2021$ by author(s) and Scientific Research Publishing Inc. This work is licensed under the Creative Commons Attribution International License (CC BY 4.0).

http://creativecommons.org/licenses/by/4.0/

\begin{abstract}
There have been significant changes over the past 20 years in the way of planning the primary schools in Portugal. As a school network forward planning instrument, the education charter was decisive in this change. At a time when the first generation education charter is concluded and a new cycle of the school network reorganisation is beginning, this article aims, based on the analysis of 34 municipalities, to reflect on the heterogeneity in the appropriation of the regulatory norms in the implementation of the first generation education charter, integrating the diverse decisions made in the various contexts. Building on the identification of the reorganisation tendencies of the school network, this article aims to assess the degree to which the proposals presented have been achieved and the results thereof.
\end{abstract}

\section{Keywords}

First Generation Education Charter, Reorganisation of the School Network, Municipal Planning

\section{Introduction}

The fact that the concentration of the population along the coast, the urbanisation of the Portuguese population, the decrease in school population, the emergence of new education models and the lack of investment in the refitting of the school network ${ }^{1}$ coexisted in time after the end of the Estado Novo period ${ }^{2}$ and of the advent of democracy led the Portuguese primary school network ${ }^{3}$ to be physically and functionally unfit: scattered and isolated schools, low levels of at- 
tendance and lack of means and resources in low density areas and overcrowded schools unable to operate in normal schedules and to provide spaces of ExtraCurricular Activities (ECA) in high density areas (Barreto, 2000; Justino, 2017; Mendes, 2018; Stoer, 1986).

Following the publication of the Basic Education System Law (BESL) ${ }^{5}$, in 1986 (Law 46/86, of 14 October), which established, for the first time, the general framework for the Portuguese education system, we see the school network planning being addressed in the national educational agenda and, under the contagious effect of the global crisis of the central administration model, the decentralisation of education and the involvement of municipalities being called on, aiming to bring political decisions closer to local realities (Ajuntament de Barcelona, 1990) and, on the other hand, to pursue an efficient and effective management of public funds, which the economic globalisation process, increasingly deregulated, were made scarcer and less clear in its distribution and use (Cordeiro \& Alcoforado, 2018; Santos, Alcoforado, \& Cordeiro, 2017). Perhaps for these reasons many of these processes appeared connected with expectations and distrust at various levels. It is vital that research helps create participatory dynamics that can problematize these uncertainties, helping to transform them into better quality actions in the defense of public education, thought and designed to respond to the more effective needs of people and their contexts (Freire, 2001).

However, despite the transformation that led to the establishment of the school charter $^{6}$ as the municipal planning approach in Law 159/99, of 14 September ${ }^{7}$, the required refitting was not achieved and Portugal entered the 21st century with an inadequate primary school network in dire need of an overall refur-

${ }^{1}$ The need to respond to the rising social demand for education in the early years of democracy determined that the education policies should focus on middle, secondary and higher education schools, to the detriment of the required structural intervention in the existing school network (Justino, 2017), especially that of primary school.

${ }^{2}$ Authoritarian, anti-parliamentary and corporative State regime that ruled in Portugal for 41 consecutive years, from the approval of the 1933 Constitution to when it was overthrown by the Revolution on 25 April 1974 (Rosas, 2012).

${ }^{3}$ For students aged between 6 and 9 years.

${ }^{4}$ Optional activities of a mainly entertainment, formative and cultural nature that determine that schools must be open until 5.30p.m. (Ordinance 644-A/2015, of 24 August). They were set up under the Full-time School Programme, launched in 2005 to make up for the delay of the Portuguese education system and promote the upgrading of the training and qualification level of future generations.

${ }^{5}$ The publication of the BESL represents the culmination of a cycle of ideology, political and administrative changes in education that creates the conditions needed for stabilising and organising the education system, bringing the standardisation phase to an end and opening up a new reform cycle (Teodoro, 2001).

${ }^{6}$ Idealised as a one-off diagnosis, to take stock of the situation and not to be seen as a projective resource, to survey and characterise the education system, the education charter was the first attempt to reorganise the Portuguese school network. Although innovative from a formal point of view, the lack of regulations and funding determined that it would only be carried out by a very small number of municipalities (Alcoforado, Cordeiro, \& Ferreira, 2012; Cordeiro \& Martins, 2013; Justino, 2017; Pacheco, 2012).

${ }^{7}$ Establishes the framework for the transfer of tasks and competences to local governments, and defines that the municipal bodies responsible for education must draft the education charter, thus giving, for the first time, municipalities the power to plan the school network. 
bishment.

The necessary changes in the primary school network were only made possible with the publication of Decree-law 7/2003, of 15 January $^{8}$, which solves the shortcomings of the school charter and lays down the education charter. In terms of concept, it abandons the traditional planning model ${ }^{9}$ and applies the principles of strategic planning ${ }^{10}$ (Santos, Cordeiro, \& Alcoforado, 2014), establishing itself as a forward means of planning and managing educational buildings and facilities at municipal level. In terms of operation, it regulates the process of elaboration and approval as well as its effects and ensures the financial resources for its implementation, allocated from the National Strategic Reference Framework (NSRF) 2007-2013.

However, the improvement was not enough to motivate the municipalities, and between 2003 and 2005 only 24 of the 308 Portuguese municipalities implemented the first generation education charter (Rodrigues, 2010). To speed up its implementation, in 2005 the Ministry of Education (ME) concluded an agreement between the government and the municipalities with a view to defining the competences of each entity, the State funding needed for its implementation, the education charter model ${ }^{11}$ and the terms under which the primary school network was to be organised. The intention was to create the physical conditions needed to concentrate the school population in larger schools, end the doubleshift school arrangement, do away with precarious school buildings and suit the spatial-functional conditions to the educational requirements, proposing to close down schools with fewer than 10 students $^{12}$ and to create new school establishments $^{13}$ to achieve this objective. Thus, from 2005 onwards the municipalities moved forward with their first generation education charters, most of which were evaluated and approved between 2006 and 2010. The whole process was supported by the national primary school and preschool network refurbishment programme, set up in 2007 to ensure equal opportunity of access to education

\footnotetext{
${ }^{8}$ Although the competences were formally assigned by Law 159/99, of 14 September, this Decree-law effectively transferred these competences for drafting the education charter.

${ }^{9}$ This model was characterised by its centralised, technocrat, rigid, reactive and non-prospective nature and for the use of plans, with the purpose of complying with the defined structure, not providing for the adaptation to reality and change, nor the anticipation of scenarios (Cordeiro, Martins, \& Ferreira, 2014).

${ }^{10}$ It appears in the 1980s as opposed to the traditional planning and is characterised by its decentralised, participated, flexible, proactive and prospective nature and by prioritising the planning process over the traditional plan (Cordeiro, Martins, \& Ferreira, 2014).

${ }^{11}$ The municipalities that started or even concluded this process in a previous phase, at the time of the school charter version, undertook to adapt the documents, integrating the adjustments defined by the ME.

${ }^{12}$ Between 2005 and 2009 schools with less than 10 students were closed down and from 2010 onwards the number was set to 21 students by Resolution of the Council of Ministers 44/2010, of 14 June. According to data from the Institute of Financial Management of Education (IFME), approximately 2500 schools were closed down between the 2005/2006 and 2009/2010 academic years.

${ }^{13}$ Buildings that should desirably integrate primary school and preschool and offer multipurpose facilities such as cafeteria/multipurpose hall, library/computer room, staff room/parents' meeting room, covered and open-air outdoor areas and sports facilities, aiming to improve the quality of the school space for both students and teachers and to be shared with local communities (ME).
} 
spaces endowed with the necessary resources conducive to educational success and to regulate the access scheme to the said community funding.

The first generation education charter made a significant change to the primary school network (and, consequently, preschool network) on a scale previously known only when the Centenary $\mathrm{Plan}^{14}$ was implemented, but now with a different meaning. The criteria of location, size and architectural and functional adequacy were changed and today the primary school network is more concentrated and updated, including schools and typologies more suited to broader educational requirements (Azevedo, 2014). Instead of having scattered small schools (with one or two classrooms) and single-level education, with one teacher only and no additional support facilities (cafeteria, library and sports facilities), schools are now centralised, have at least four classrooms (to ensure one classroom and one teacher per school year), have different education levels and the necessary means and resources.

The first generation education charter created the conditions for the municipalities to reorganise their primary school network, enabling them to "find local education solutions in the national political context" (Matthews, Klaver, Lannert, Ó Conluain, \& Ventura, 2009: p. 38), thus marking the conclusion of the conceptual and methodological change process initiated by the BESL (Cordeiro, Martins, \& Ferreira, 2014). After a long period of centralism, this move was a major step towards achieving decentralisation, with a shift from a top-down sort of arrangement to another of a bottom-up nature (Cordeiro, 2014).

The first generation education charter mirrored a complex local policy building process that endured much pressure with decisive influence on the various decision-making phases and levels. As the preparation phase is already well investigated, at a time when the revision of the education charters (second generation) are under way, the analysis of the execution phase, a topic still little investigated, seems to be an interesting subject of study to thoroughly understand the reorganisation process of the Portuguese school network. With this in mind, this article is divided into two parts: the first one builds on the observation of the predominant traits and more distinctive characteristics of each school network reorganisation, identifies and interprets the type of planning solutions adopted by the municipalities under analysis; the second part assesses the different levels of achievement of the proposals submitted, highlighting and interpreting the deviations by comparison with initial forecasts, and compares its effective contribution to the modernisation of the Portuguese school network and, in particular, to the promotion of equal opportunities in the education system.

This work is based on a qualitative research developed, in a first phase, through the analysis of national regulations and relevant scientific literature and, in a second phase, of numerous case studies. To ensure a broad strategic vision of the diverse national territory, we have considered two Intermunicipal Com${ }^{14}$ Launched during the New State period, in 1941, the Centenary Plan consisted of a plan to build primary schools to allow all children to attend school. 
munities (IMC) $)^{15}$ in the central region of Portugal: Coimbra Region $\mathrm{IMC}^{16}$ and Beiras and Serra da Estrela $\mathrm{IMC}^{17}$, which include 34 of the 100 municipalities that make up the region and form a strip of land that stretches from the coast to the interior consisting of municipalities marked by very different physical, demographic, socioeconomic, cultural, educational and political realities (Figure 1). This will give us a picture of the different questions that arise in territories with such different realities, will allow us to identity the aspects that have influenced the most the decisions made during the implementation of the first generation education charters, and gather proof that although the guidelines are conducted along national lines, the country has evolved at very different paces, with territorial dynamics strongly interfering in the choices and progress made.

\section{Local Policy Options for Reorganising the School Network: Main Trends}

In spite of the incredible effort made, drafting the education charter did not go as planned. Although it might be said that it reflected a new structural vision of the Portuguese education system and constituted a major step towards the engagement of the municipalities in the educational system and their joint responsibility for the results, the announced decentralisation never materialised and the school network plan was kept under strong State scrutiny. The municipalities had to deal with the clear contradiction between having, for the first time, the opportunity to actively participate in the discussions of the solutions for reorganising their preschool and primary school network and, simultaneously, having to comply with the guidelines defined at central level concerning which schools to close and the type, size and characteristics of the educational buildings to be created, on which the approval of the education charters by the ME and the community funding depended (Neto-Mendes, 2007).

The double standards of the State and society's natural opposition to change made the municipalities react very distinctly when the proposed reorganisation of the school network was drafted. A previous research (Cordeiro \& Martins, 2013) carried out in 14 municipalities of the central region of Portugal between 2009 and 2011 exemplified some characteristics that distinguished three types of solutions for school network reorganisation: the central type, "when the proposed solutions for the reorganisation of the school network run fully parallel with those defended by the Central State", the conciliation type, "when the solutions found tend to harmonise the solutions determined by the State with those defended by the municipality", and the municipal type, "when the prevailing so-

\footnotetext{
${ }^{15}$ Correspond to level III administrative units in the Nomenclature of Territorial Units for Statistics (NTU), a hierarchical system for dividing the territory into regions, which is sub-divided into three levels (NTUS I, NTUS II, NTUS III), defined by reference to population, administrative and geographical criteria (Pordata).

${ }^{16}$ Consists of 19 municipalities, of which only seven have not been classified as low density territories (Cantanhede, Coimbra, Condeixa-a-Nova, Figueira da Foz, Mealhada, Mira and Montemor-o-Velho).

${ }^{17}$ Consists of 15 municipalities, all of which are of low density.
} 
lutions correspond mostly to the interests of the various local players, superimposing or ignoring, to a great extent, the criteria and objectives defined at central level" (Cordeiro \& Martins, 2013: pp. 351-353) ${ }^{18}$. This study, based on a sample that provides for broader territorial characteristics and a greater geographical diversity, at a time when final results can be presented, confirms and reaffirms the three patterns established previously and identifies the prevailing trends (Figure 2).

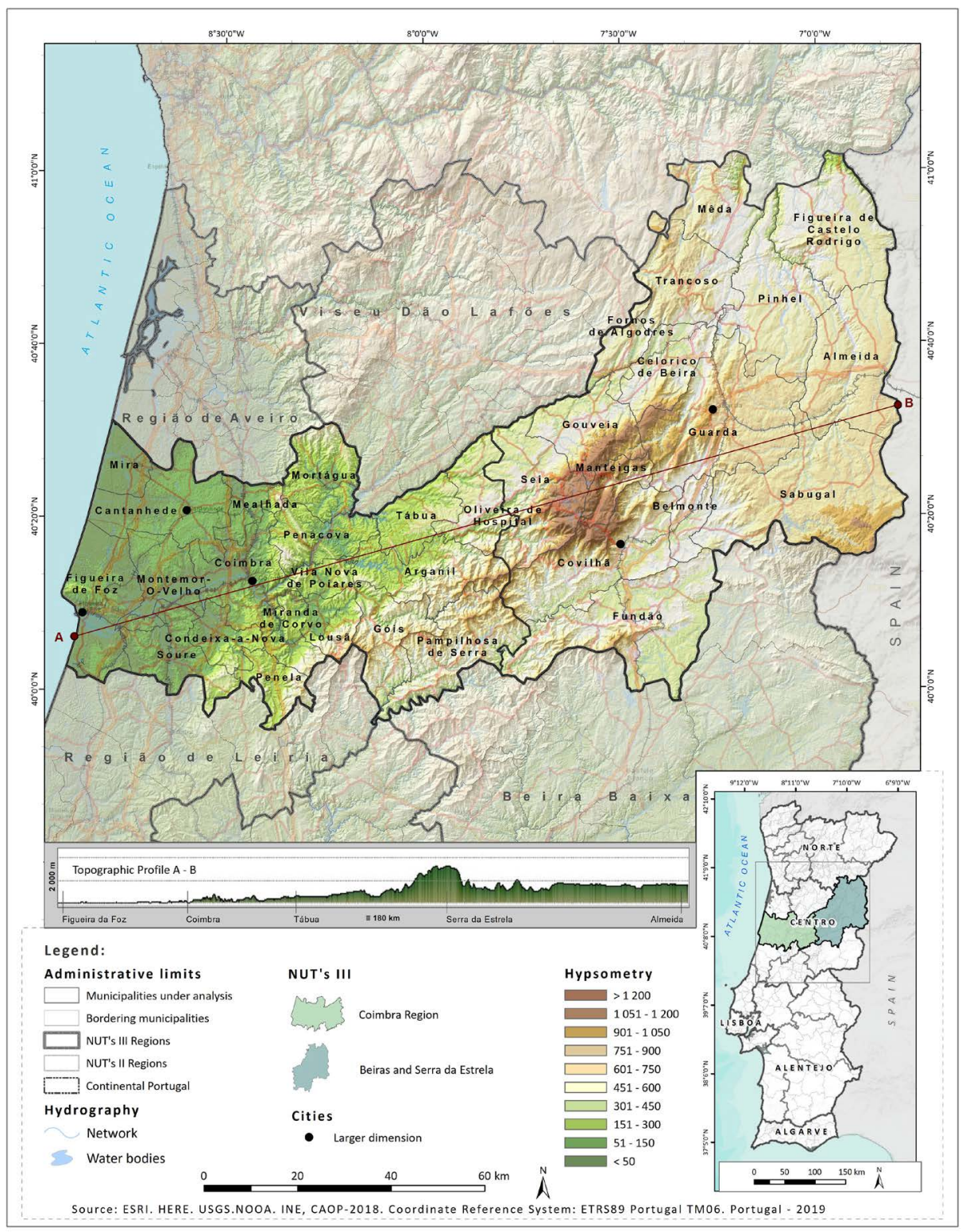

Figure 1. Geographical situation in the municipalities under analysis. Source: Self elaboration.

\footnotetext{
${ }^{18}$ Although this analysis supports the three solutions for the school network reorganisation and their distinctive features identified in the previous research (Cordeiro \& Martins, 2013), we felt it was advisable to use new designations for the "determined" type, which we have called "central", and "community" type, which we have called "municipal", and to maintain the same designation for the "conciliation" type. Seen from afar, we believe that these new designations better reflect the choices and experiences developed.
} 


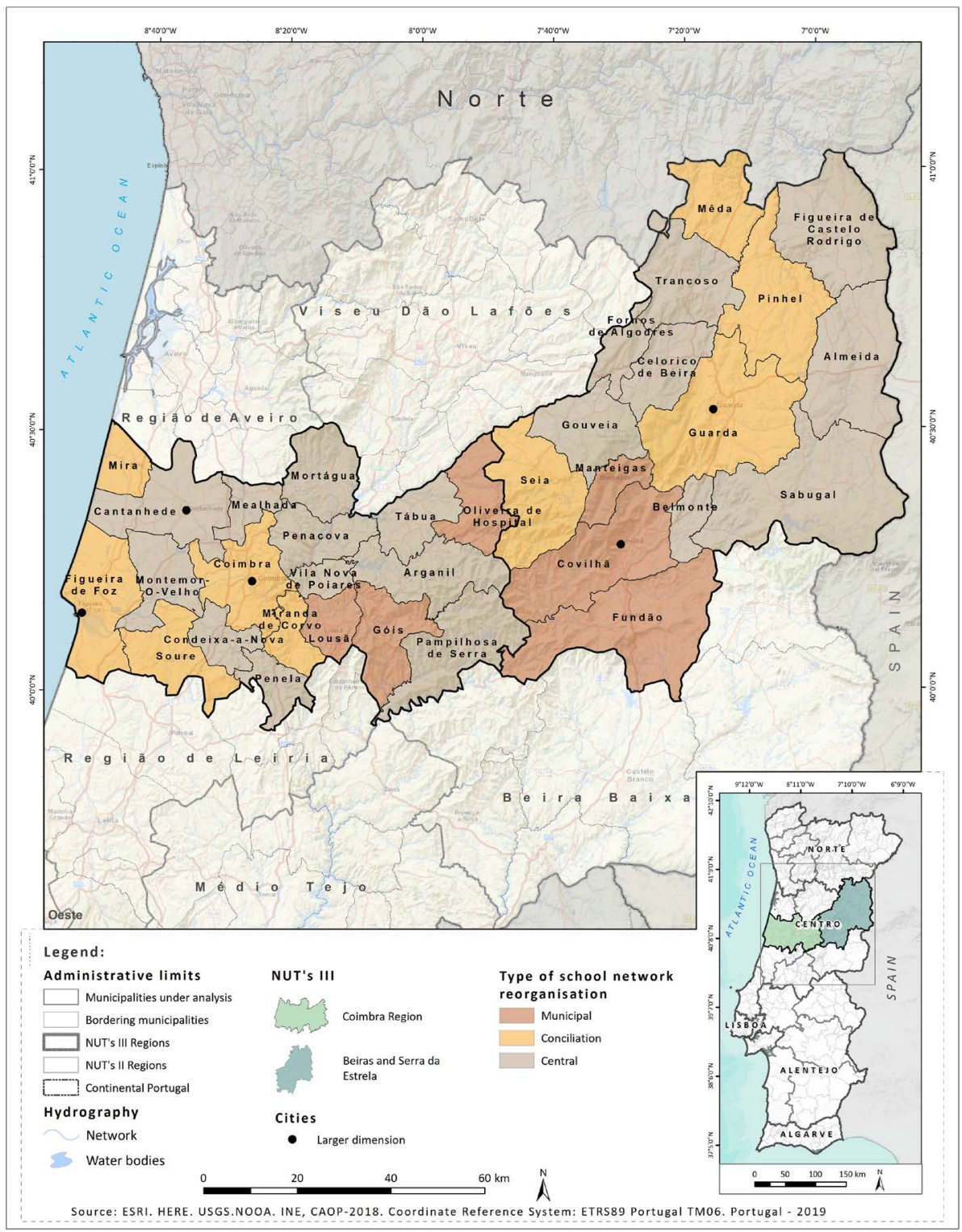

Figure 2. Solutions for the reorganisation of the school network. Source: Self elaboration.

\subsection{The Central Type}

The first idea that stems from the analysis of the 34 municipalities is that despite the obvious differences in terms of their physical, demographic and socioeconomic context, when municipalities had to make a decision, most of them (19) were concerned to prepare the school network for the challenges ahead and chose to follow the rationality and quality criteria defended by the education authority and to propose the closing down of isolated and/or small schools and the concentration of the school population in new school establishments (either by building new ones or refitting existing ones).

Four of the seven municipalities not classified as low density territories fall into this group (Cantanhede, Condeixa-a-Nova, Mealhada and Montemor-o-Velho). At the base of this central type of school network reorganisation, where the role 
of the municipality was simply to translate the guidelines issued at central level and the proposals fully tallied with the technical-political objectives defined by the State (Cordeiro \& Martins, 2013; Cordeiro, Martins, \& Ferreira, 2014), was the will to ensure equal conditions for access to quality education for all students, removing the imbalances between the central sectors, more urban, and the peripheral sectors, more rural, but also the need to conform with national requirements to obtain community funding for the works to be carried out. Here we were working with a local regulation (municipality and education community) without severe tensions, whose interests were compatible with the national education policies and committed to the value of a technically-competent proposal (Cordeiro \& Martins, 2013; Cordeiro, Martins, \& Ferreira, 2014).

The municipalities of Fornos de Algodres and Mortágua are the ones that best represent this type of school network reorganisation, presenting two of the most successful solutions. They proposed the construction, from scratch, of a single school establishment in the council's parish seat to accommodate all children and reduce their commute time (Fornos de Algodres Municipality, 2007; Mortágua Municipality, 2007). With this in mind, they sought to provide all the physical, spatial and material conditions, in their territory that were best suited to the roles assigned to school today.

\subsection{The Conciliation Type}

A second smaller group (9) sought to match the assumptions of rationality and quality as determined by the ME with the logic of respect for the local specificities defended by the local authorities and applied different criteria for the planning solutions presented, proposing to create new school establishments in some sectors of the municipal territory and maintain obsolete primary schools in others. These municipalities that followed a conciliation type strategy were not concerned with decreasing inequality of opportunities in the primary school, increasing the existing territorial imbalances, which motivated this intervention in the school network. This was the solution chosen by the two largest cities of the Coimbra Region IMC, Coimbra and Figueira da Foz, high density areas, and also by the second largest city of the Beiras and Serra da Estrela IMC, Guarda, globally classified as a low density territory. In this type of school network reorganisation in which the role of municipalities was to jointly find solutions for their territory and who sought to harmonise the State's objectives with the interests of the municipalities, the proposal is based on a "low density political context" where the local and central powers try to find answers that satisfy all stakeholders "through a blended process of gains and losses" (Cordeiro \& Martins, 2013: p. 352).

The municipalities of Guarda and Soure are two examples of this type of school network reorganisation. Guarda municipality proposed the creation of several school establishments (mostly through refitting works), strategically distributed so as to cover all of the municipal territory, and, at the same time, the maintenance of a large number of schools to cover the increasing demand 
in the urban centre, the large territorial extension, the evident natural handicaps and the low density in the rural sectors (Cordeiro, 2008). Through this solution, the local power sought to respect the various physical, demographic and socioeconomic realities and to curb the strong concentration in the urban centre and the growing desertification of the rural sectors. Soure municipality, in turn, opted to thoroughly rehabilitate the existing schools with a stable and significant number of students and to build new school establishments to provide appropriate conditions to current education and family requirements (Soure Municipality, 2006).

\subsection{The Municipal Type}

A smaller number of municipalities (6), all classified as low density territories, decided to override the criteria and objectives defined at central level with the interests of local political and social players and did not propose structural changes to the type and geographical distribution of the school network, providing only the host schools for schools expected to have low-attendance. These municipalities, in which "the local political strength and influence" sought to "set to one side or even contradict the political-normative strength of the central power" (Cordeiro \& Martins, 2013: p. 353) and where the solutions found were mostly adjusted to the interests of the local community, were not concerned with providing the adequate educational buildings and facilities to effectively respond to the increasing education requirements and to ensure the conditions of quality, equality and equity, which are today acknowledged as the features of a public education service. As a result, we still find local and regional asymmetries that negatively distinguish the low and high density areas. The municipal type of school network reorganisation, typical of low density territories, builds on the realisation that in these territories the schools are structural facilities for a spatial planning consistent with social cohesion. Hence, the decision to close them should not be based on quantitative criteria alone, but rather take into account the differences in the national territory. This was the option followed by the city of Covilhã, the largest city of the Beiras and Serra da Estrela IMC. In contrast to the central type of school network reorganisation, in this type political tensions ran high between the municipality and the State and the local logic of the administered prevailed over that of the administrators (Cordeiro \& Martins, 2013).

In the municipalities of Manteigas and Fundão, the argumentation closest to the local power and community is certainly present. As regards Manteigas, the proposal for the school network reorganisation considered maintaining all schools, with only some undergoing construction work, repair and rehabilitation (Manteigas Municipality, 2007). As for Fundão, besides the refitting of the existing school network, the proposal was to also transform an underutilised middle school ${ }^{19}$ into an integrated middle school with a kindergarten ${ }^{20}$, to prevent it from being emptied out and ensure a more effective management of existing re${ }^{19}$ For students aged between 10 and 14 years.

${ }^{20}$ For students aged between 3 and 14 years. 
sources (Fundão Municipality, 2006).

In summary, the results of this empirical study have allowed us to conclude that the central type of school network reorganisation is mostly associated to technical-administrative rationale, while the conciliation or municipal types are predominantly due to political reasons, although often influenced by local constraints, such as the distance between schools, physical constraints and low density.

\section{Implementation of the Proposals for the School Network Reorganisation: What Was Planned and What Has Been Achieved}

The reading of the reality in the 34 municipalities of the central region of Portugal under study shows that the conceptual plan and the operational plan were not always aligned when it came to implementing the proposal for the school network reorganisation as per the education charter (Figure 3 ). The data show that although most municipalities chose to fully (total) or close to fully (partial high) conform to the defined strategy, showing that when it was drafted they did intend to achieve it, the number of municipalities where this did was not the case was quite significant. Departures from the programme initially set are almost always due to internal difficulties, even if external factors, beyond the scope of the municipalities, were responsible for the introduction of more or less specific changes. Non-conformity is, therefore, more of a consequence than a motive of the actions taken.

If we draw a parallel between the type of proposal for the reorganisation of the school network presented in the education charter and the degree of implementation in all the 34 municipalities under analysis, we can conclude that compliance with the intention and the action is greater in the municipalities that adopted the municipal type solution, which was expected (Figure 4). The lack of structural changes to the school network, the low investment involved and the close alignment between the local political and social interests seem to be some of the main reasons for the high level of achievement found in these territories. In these cases, the existing deviations are mostly due to the drop in school attendance, which in many low density territories forced the unplanned close down of small schools and the concentration of the school population ${ }^{21}$. See, for example, the case of the municipality of Covilhã, where the strong drop in the number of students dictated a reorganisation of the municipal school network. In other cases, the changes to the initial project were caused by the change of the ruling municipal power, which almost always resulted in a more or less abrupt change in the course of the local education policy. Note the case of the municipality of Oliveira do Hospital, where the new political team took a fresh look at

${ }^{21}$ Many of these territories opposed the closing down of small schools as imposed by the ME and entered into complex negotiations with the ministry to establish new minimum limits that would allow them to remain open, trying to prolong their operation until the number of students reached a threshold that would make the closing thereof inevitable. 
the strategy for the intervention in the school network and proposed the construction of an unplanned school establishment, showing, unlike the previous one, some concerns with the renewal of the types of primary schools.

In contrast, the difference between what was originally planned and what was actually achieved is more significant in the municipalities with a conciliation type of reorganisation. The poor implementation rate appears to relate to the double standards that characterise this type of school network reorganisation, the opposition of the local community to the closing down of primary schools, the lack of political will to go ahead with the reconfiguration of the school network, the weaknesses of the local players and the difficulty in obtaining funding for all the programmed projects, which forced the prioritisation of investments.

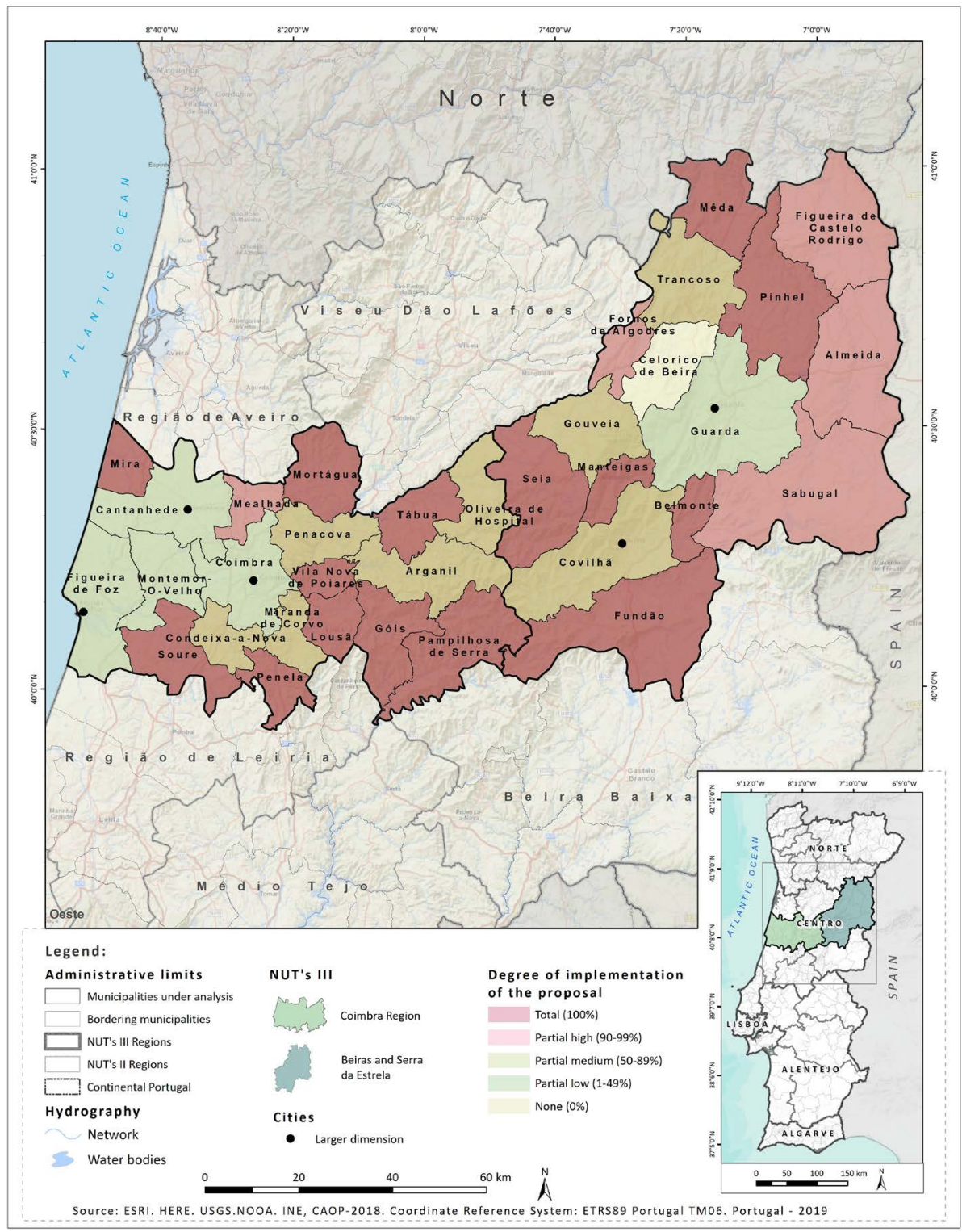

Figure 3. Degree of implementation of the proposals for the school network reorganisation. Source: Self elaboration. 


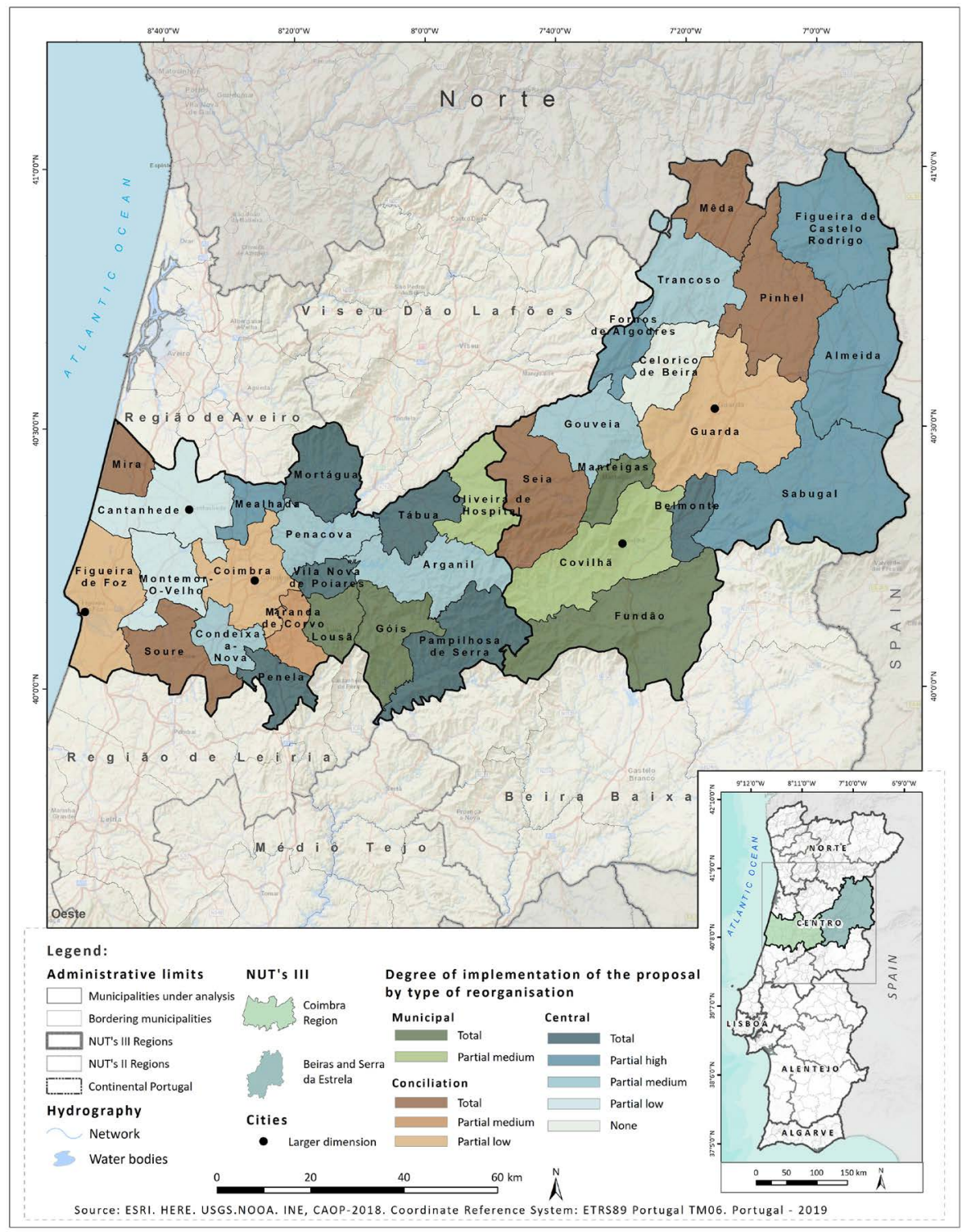

Figure 4. Relation between the school network reorganisation solutions and the level of implementation of the proposals. Source: Self elaboration.

With the exception of the municipality of Miranda do Corvo, it is the large cities that fail to comply with the plans (Coimbra, Figueira da Foz and Guarda). The municipalities of Figueira da Foz and Guarda are of particular note, as their level of implementation is far below the expected target. In the former, three of the eight planned school establishments were built, two in the urban areas and one in a peri-urban parish. In the latter, three of the eleven planned school establishments were built, one in the urban centre, to meet the increasing demand, and two in the rural areas, as territorial clusters. Although the number of primary schools dropped significantly, especially in the Guarda municipality, due to its declining demography, which led to the closure of more than two dozen small schools, in both cases more schools than had been planned continued in operation. 
Finally, the implementation rate is also low in the municipalities that opted for the central type of school network reorganisation. The reasons which can justify the non-compliance with the set programme include the different political drives in what comes to facing the opposition of the local populations regarding the closing down of small schools and the modernization of the school network, the gradual drop in the school population, which made some of the planned measures unnecessary, and the investment required for implementing some of the proposals, which imposed that the interventions had to be prioritised. Indeed, while on the one hand the objectivity of this type of reorganisation solution, that aimed for the full renewal of the primary school network, made it quite unique, it was also its greatest obstacle when it came to making it operational, as it required greater financial resources than the other typologies. This was the case of the municipalities of Cantanhede and Montemor-o-Velho, where only three out of nine planned school establishments were created for the former and one out of four in the latter case. In these territories, the choice fell on the construction of new school establishments in urban centres and in the main population centres and on maintaining the existing primary schools in the rest of the territory, clearly out of line with the current reference standards. As for the municipality of Trancoso, non-compliance was due to the drop in the number of students in the middle school, which freed up space to accommodate primary school students and made the construction of the new block designed for this level of education unfeasible. Regardless of the reasons for not complying with the planned strategy, the fact is that except for the municipality of Mealhada, the high density municipalities found it more difficult to implement the proposal for the school network reorganisation contained in the education charter.

Although all the relations that can be established between the type of proposal for the school network reorganisation in the education charter and the level of compliance are valid, and despite all the justifications we can find to support them, often the non-compliance with the defined strategies is due to the fact that many of these strategies were designed with one single purpose: to fully observe the requirements necessary for the ME to approve the education charter and for obtaining the community funding, and not its actual implementation. Only the investments considered as a priority were provided for, usually located in densely populated areas.

\section{Results Achieved with the School Network Reorganisation}

In terms of the results achieved, and again based on the reality in all the $34 \mathrm{mu}$ nicipalities of the central region of Portugal under study, they reflect the different choices made during the preparation and implementation phase of the proposal for the school network reorganisation contained in the education charter, showing major discrepancies in the teaching and learning conditions between municipalities, and even within the same municipality.

In the territories with municipal type of school network reorganisations, the geographical distribution of the school network changed little: school establish- 
ments continued scattered and the proximity logic prevailed. This is where we find a large number of small primary schools ${ }^{22}$ still in operation and the new school establishments are an exception and almost always set aside for areas in need. The result is that each parish still has one school and there is hardly any increase in the number of students in mobility. The effects of this type of school network reorganisation are felt the most in the rural areas, as this is where the operational conditions of school establishments are usually the worst.

The result of the implementation of the central type of school network reorganisations was that instead of having scattered schools, their location became concentrated, revealing the rational logic overlapping the traditional proximity logic. The most visible impacts include the closing down of many primary schools, the increase in the number of parishes without any educational courses being offered to this level of education, the significant growth in the number of students in mobility and the recognition of the new school establishments as the best solution for solving the problems of the primary school. Note that the location of the new school establishments took into consideration reasonable commutes between home and school, considering the distance travelled and the duration thereof, so that students do not have to spend a long time in the commute, but also to reduce school transport costs.

Municipalities where the conciliation type of school network reorganisation was implemented and the remaining territories ${ }^{23}$ show mixed solutions, where areas with scattered schools and those in which the schools are concentrated coexist in the same territory. Here, rationality was brought into line with proximity: in low density territories the logic of one school per parish was adopted and the schools inherited from the Centenary Plan continued to operate, closing only those imposed by the ME due to the school attendance reduction; in urban territories the option was to close down small schools and concentrate the population in new school establishments. The result of the double standards, embodied in the coexistence of different types of primary schools, was that the increase in the number of students in mobility was felt only in some areas of the municipal territory. In these municipalities, the inequality of opportunities that motivated this deep intervention in the school network became even more pronounced.

This analysis shows that despite the significant planning work done, visible in the nearly two hundred primary schools being closed down and in the more than forty school establishments built/refitted (Table 1), in many cases the only changes to the primary school network were those resulting of the increasing decline in school attendance, which led to the gradual closing down of small schools. The result in these territories was the preservation of a school network mostly characterised by unattractive and hardly functional buildings, with less than four classrooms, and, therefore, unable to ensure one classroom and one ${ }^{22}$ In most cases, only the schools with declining school attendance were closed down.

${ }^{23}$ Including the municipalities who partially implemented the central type of school network reorganization. 
teacher per school year, in addition to having few students in the different years of schooling ${ }^{24}$.

Table 1. Schools closed down and school establishments built/refitted between 2005/2006 and $2009 / 2010$.

\begin{tabular}{|c|c|c|c|c|}
\hline $\begin{array}{l}\text { Intermunicipal } \\
\text { communities }\end{array}$ & Municipalities & $\begin{array}{l}\text { School network } \\
2005 / 2006\end{array}$ & $\begin{array}{l}\text { Closed down } \\
\text { schools }\end{array}$ & $\begin{array}{c}\text { Built/refitted school } \\
\text { establishments }\end{array}$ \\
\hline \multirow{19}{*}{ Coimbra region } & Arganil & 21 & 7 & 3 \\
\hline & Cantanhede & 46 & 17 & 3 \\
\hline & Coimbra & 89 & 13 & 6 \\
\hline & Condeixa-a-Nova & 16 & 4 & 1 \\
\hline & Figueira da Foz & 56 & 12 & 3 \\
\hline & Góis & 7 & 1 & 1 \\
\hline & Lousã & 14 & 2 & 1 \\
\hline & Mealhada & 23 & 11 & 1 \\
\hline & Mira & 13 & 3 & 1 \\
\hline & Miranda do Corvo & 16 & 3 & 1 \\
\hline & Montemor-o-Velho & 31 & 4 & 1 \\
\hline & Mortágua & 22 & 8 & 1 \\
\hline & Oliveira do Hospital & 29 & 8 & 2 \\
\hline & Pampilhosa da Serra & 8 & 0 & 1 \\
\hline & Penacova & 27 & 11 & 1 \\
\hline & Penela & 12 & 4 & 2 \\
\hline & Soure & 32 & 5 & 3 \\
\hline & Tábua & 22 & 2 & 1 \\
\hline & Vila Nova de Poiares & 9 & 1 & 3 \\
\hline \multirow{16}{*}{$\begin{array}{c}\text { Beiras and } \\
\text { serra da Estrela }\end{array}$} & Almeida & 13 & 0 & 0 \\
\hline & Belmonte & 11 & 3 & 0 \\
\hline & Celorico da Beira & 26 & 8 & 0 \\
\hline & Covilhã & 41 & 4 & 0 \\
\hline & Figueira de Castelo Rodrigo & 15 & 2 & 0 \\
\hline & Fornos de Algodres & 14 & 1 & 1 \\
\hline & Fundão & 33 & 4 & 0 \\
\hline & Gouveia & 22 & 5 & 0 \\
\hline & Guarda & 63 & 10 & 3 \\
\hline & Manteigas & 4 & 2 & 0 \\
\hline & Mêda & 11 & 2 & 1 \\
\hline & Pinhel & 26 & 3 & 0 \\
\hline & Sabugal & 27 & 7 & 0 \\
\hline & Seia & 44 & 4 & 2 \\
\hline & Trancoso & 22 & 14 & 1 \\
\hline & Total & 865 & 185 & 44 \\
\hline
\end{tabular}

Source: Self elaboration.

${ }^{24}$ In many of these territories, the provision of better physical, material and human conditions for the school population that had moved to the host schools was not always safeguarded. 
Despite the deviations from the initial objectives and the different results achieved, the education charter served as a legitimising instrument to speed up the Portuguese primary school network reorganisation, which now is more in line with the education ideal and with current social dynamics (Photo 1 and Photo 2). Some of its most outstanding aspects are the closing down of thousands of small primary schools and the proliferation of new school establishments. According to IFME data, while the education charter was being drafted and implemented, which took place mostly between 2005 and 2010, more than 2500 small primary schools were closed down and about six hundred school establishments were built. The change embodied in the education charter and anchored in stringent development criteria marked the beginning of a new evolutionary cycle of education in Portugal, moving from the "crisis of problems" to the "crisis of solutions" (Barroso, 2003).

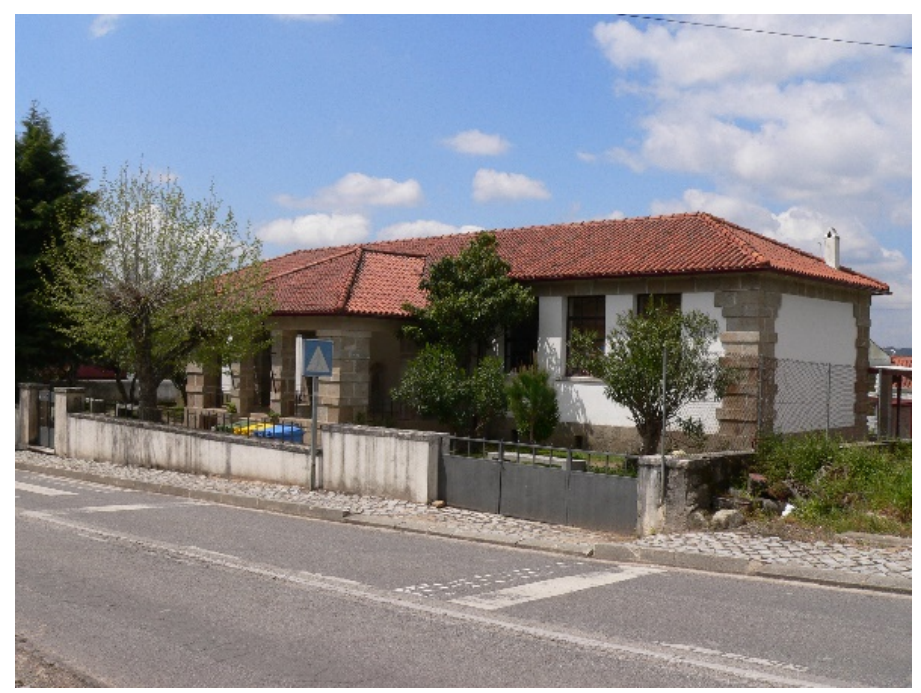

Photo 1. Front view of the Espinhal primary school-Penela Municipality. Source: Self elaboration.

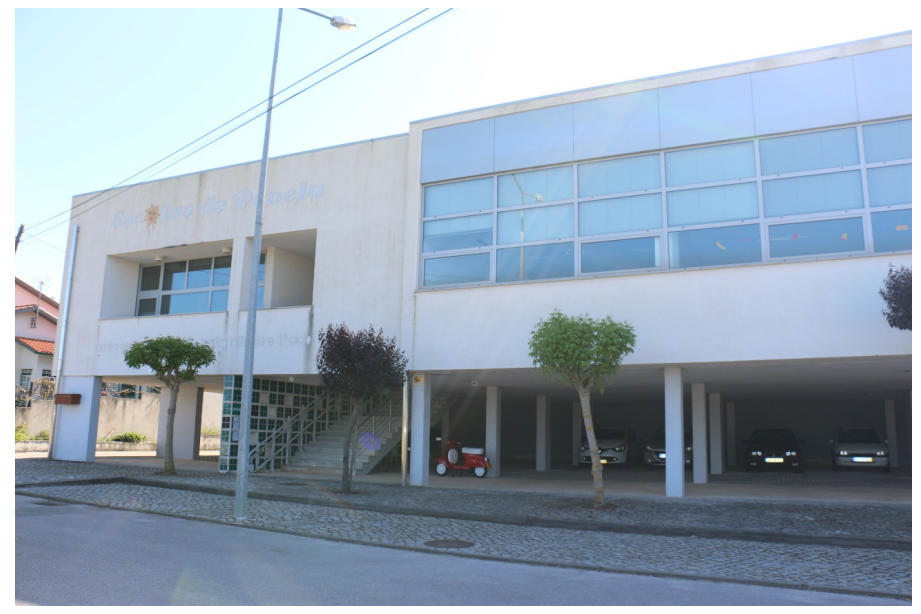

Photo 2. Front view of the Espinhal new school establishmentPenela Municipality. Source: Self elaboration. 


\section{Concluding Remarks}

The profound demographic, socioeconomic and educational changes that Portugal lived in the last decades of the 20th century created a strong imbalance between school demand and offer in the primary school, visible in the isolated small schools in low density areas and overcrowded schools with double-shift arrangements in urban centres. In view of these structural problems, the Portuguese government placed the school network planning on the national education agenda in the early years of the 20th century, completely changing the paradigm in force with further decentralisation and adopting new planning methods. The education charter served as the instrument of this change that allowed the municipalities, for the first time and almost two decades after the publication of the BESL, to consider the Portuguese primary school network in the light of the actual reality and of the expected societal changes.

But, although the education charter opened the discussion to the whole society and effectively contributed to the Portuguese public primary school network reorganisation, the whole process did not go as planned. The research done in this paper shows a clear strategic ambiguity in local choices during the drafting and implementation phases of the education charter, as a result of the national guidelines being accepted differently by the local powers and communities, mainly tied with political, demographic and pedagogical issues. As a result of the heterogeneous municipal argumentations, today (as opposed to the beginning of the second half of the 20th century) we are seeing a broad variety of situations, for example, in some municipalities the school network is fully refitted, in others the new educational buildings coexist with old primary schools and in others little or nothing has changed, except for the forced closing down of schools due to the decline in the school population.

A second idea that can be drawn from this analysis is that, contrary to what one might have thought, it is not the municipalities with a stronger population and economic dynamic that are more concerned about the refitment of the school network. The results of this comparative study show that the more profound interventions in the school network are found in low density territories and, conversely, the more densely populated areas find it more difficult to push for the reorganisation of the school network. It thus becomes clear that when it comes to defining the municipal education strategy and make decisions, the local political issues prevail over the demographic, economic and pedagogical issues.

To conclude, although the involvement of municipalities in the definition of the education policy fared well, the entire process was regulated by the central power. Strengthening local autonomy did not happen as announced and the interests of the municipalities came up against the rules defined at central level and communicated to the municipalities to be implemented, as was the case of the closing down of small schools.

\section{Conflicts of Interest}

The authors declare no conflicts of interest regarding the publication of this paper. 


\section{References}

Ajuntament de Barcelona (1990). The Educating City. Ajuntament de Barcelona.

Alcoforado, J. L. M., Cordeiro, A. M. R., \& Ferreira, S. M. (2012). The School Network (re)Organization as a Reflex of the Demographic, Political and Geographic Transformations in Portugal's Last Six Decades. In M. J. Mogarro, \& M. T. S. Cunha (Eds.), Proceedings of the IX Luso Brazilian Congress of the Education History: Rituals, Spaces \& School Patrimonies (pp. 5423-5435). Lisbon: Institute of Education of the University of Lisbon.

Azevedo, J. M. (2014). From the Centenary Plan to the School Centres Program: The Primary School Network 1960-2010. In M. L. Rodrigues (Ed.), 40 Years of Education Policies in Portugal: Knowledge, Actors and Resources (pp. 559-579). Coimbra: Almedina.

Barreto, A. (2000). The Social Situation in Portugal 1960-1999. Lisbon: Social Science Press.

Barroso, J. (2003). Organization and Regulation in the Portuguese Educational System (at both Primary and Secondary Level). Education \& Society Journal, 24, 63-92.

https://doi.org/10.1590/S0101-73302003000100004

Cordeiro, A. M. R. (2008). Guarda Education Charter. Coimbra: Faculty of Arts and Humanities of the University of Coimbra.

Cordeiro, A. M. R. (2014). The Municipalities Role in the Planning and Management of Portugal's School Network. In M. L. Rodrigues (Ed.), 40 Years of Education Policies in Portugal: The Foundation of the Education Democratic System (pp. 421-444). Coimbra: Almedina.

Cordeiro, A. M. R., \& Alcoforado, L. (2018). Public Education Policies Based on Local Realities and Dynamics: Reflections and Contributions to the Planning of Sustainable Territories and Communities. In I. M. F. Valente, \& M. C. Teixeira (Eds.), Euro-Atlantic: Space for Dialogues-Education and Freedom, Foundations for Citizenship (pp. 9-36). Campina Grande: Publisher of the Federal University of Campina Grande.

Cordeiro, A. M. R., \& Martins, H. A. (2013). The Municipal Education Charter as a Strategic Instrument for the School Network Reorganization: Changing Tendencies. Geography Notebooks, 32, 339-356. https://doi.org/10.14195/0871-1623 $32 \quad 30$

Cordeiro, A. M. R., Martins, H. A., \& Ferreira, A. G. (2014). Municipal Education Charters and the School Network Reorganization in Portugal's Central Region: From Demographic Conditions to Political Decision-Making. Essay Journal: Evaluation and Public Policies in Education, 22, 581-608.

Decree-Law 7/2003, of 15 January. Official Journal, 1st Series-A, 12, 130-136.

Fornos de Algodres Municipality (2007). Fornos de Algodres Education Charter. Fornos de Algodres: Fornos de Algodres Municipality.

Freire, P. (2001). Education in the City. Cortez.

Fundão Municipality (2006). Fundão Education Charter. Fundão: Fundão Municipality.

Justino, D. (2017). School Organization: School Groupings. Lisbon: National Education Council.

Law 159/99, of 14 September. Official Journal, 1st Series- $A$, 215, 6301-6307.

Law 46/86, of 14 October. Official Journal, 1st Series, 237, 3067-3081.

Manteigas Municipality (2007). Manteigas Education Charter. Manteigas: Manteigas Municipality.

Matthews, P., Klaver, E., Lannert, J., Ó Conluain, G., \& Ventura, A. (2009). Primary School Education Policy (2005-2008): International Evaluation. Lisbon: Education Statistics and Planning Office, Ministry of Education. 
Mendes, M. F. (2018). The National Context: Decline in Fertility in Portugal from a Century Perspective. In J. F. M. Pinto (Ed.), Demographic Challenges: Birth Rate (pp. 2585). Coimbra: Edições Almedina.

Ministry of Education (ME). Framing Assumptions of the National Primary School and Preschool Requalification Program. http://www.centroescolar.min-edu.pt/np4/file/9/programa i.pdf

Mortágua Municipality (2007). Mortágua Education Charter. Mortágua: Mortágua Municipality.

Neto-Mendes, A. (2007). The Participation of Portuguese Municipalities in Education and State Reform-Elements for Reflection. In Education Policy and Administration National Association (Ed.), For a Quality School for All (pp. 1-22). Porto Alegre: Federal University of Rio Grande do Sul.

Ordinance 644-A/2015, of 24 August. Official Journal, 2nd Series, 164, 24284-(8)24284-(11).

Pacheco, A. O. F. (2012). Construction and Development of Local Educational Policies: The Educational Charter as a Strategic Tool. Master's Thesis, Lisbon: Lisbon School of Education, Lisbon Polytechnic Institute.

Pordata. What Are NTUS? https://www.pordata.pt/O+que+sao+NUTS

Resolution of the Council of Ministers 44/2010, of 14 June. Official Journal, 1st Series, 113, 1997-1998.

Rodrigues, M. L. (2010). Public School Can Make a Difference. Coimbra: Almedina.

Rosas, F. (2012). Salazar and Power: The Art of Knowing How to Last. Lisbon: Tinta da China.

Santos, L., Alcoforado, L., \& Cordeiro, A. M. R. (2017). Education Policies: The Different Responsibilities and Options of Public Authorities. Educational Sciences Journal, 37, 37-64.

Santos, L., Cordeiro, A. M. R., \& Alcoforado, L. (2014). The New Paradigm of School Network Planning: From Planning to Offering to Demand Planning. In A. M. R. Cordeiro, L. Alcoforado, \& A. G. Ferreira (Eds.), Territories, Educating Communities and Sustainable Development (pp. 57-67). Coimbra: Department of Geography-Faculty of Arts and Humanities of the University of Coimbra.

Soure Municipality (2006). Soure Education Charter. Soure: Soure Municipality.

Stoer, S. (1986). Education and Social Change in Portugal: 1970-1980, a Decade of Transition. Lisbon: Edições Afrontamento.

Teodoro, A. N. D. (2001). The Political Construction of Education: State, Social Change and Educational Policies in Contemporary Portugal. Porto: Edições Afrontamento. 